\title{
Special issue on protein species
}

\author{
Hartmut Schlüter $\cdot$ Peter R. Jungblut
}

Published online: 19 May 2011

(C) Springer-Verlag 2011

The great efforts of the last 20 years resulted in a highly automated and sensitive proteomics technology at the protein level with sensitive detection of posttranslational modifications on peptides. The protein expression concept was an important motor for this development. The next step in proteomics is to reach the protein species level to obtain access to the functional active molecules. Together with the amino acid sequence, the combination of the posttranslational modifications decides for the function. If we want to understand function at the molecular level, we have to learn to work with the protein species concept, which is introduced in the Editorial of the Special Issue Protein Species (Jungblut and Schlüter 2011). This Special Issue is a first attempt to show the state of the art of this concept.

There are several hundred known posttranslational modifications and because it is not possible here to consider all of them, a focus had to be set to phosphorylation (Wisniewski 2011), glucosylation (Sisu et al. 2011; Wisniewski 2011), ADP ribosylation (Laing et al. 2011), and proteases (Klein and Bischoff 2011) within four reviews. In another review, Meyer et al. (2011), the challenges to obtain $100 \%$ sequence coverage, a prerequisite to work at the protein species level, are worked out.

Four articles present technological improvements to obtain access to posttranslational modifications or even protein species. Metal ion-mobilizing additives were

H. Schlüter

Institute of Clinical Chemistry, Mass Spectrometric Proteomics, University Medical Center Hamburg-Eppendorf, Martinistr. 52, 20246 Hamburg, Germany

P. R. Jungblut ( $\square)$

Core Facility Protein Analysis, Max Planck Institute for Infection Biology, Charitéplatz 1, 10117 Berlin, Germany e-mail: jungblut@mpiib-berlin.mpg.de suggested to improve the sensitivity of phosphopeptide detection (Seidler et al. 2011). An optimized scoring for different charge states and cleavage improved the identification of $O$-linked glycopeptides from ETD data (Darula et al. 2011). Hoehenwarter et al. (2011) applied linear mathematics for functional analysis of proteins and protein species using shotgun proteomics. In-capillary proteolytic digestion was applied for direct analysis of alpha- and betachains of hemoglobins from mammalian blood samples by nano-ESI mass spectrometry (Henning et al. 2011).

In six biological applications protein speciation was observed and it becomes obvious that it is necessary to improve protein-chemical methods to reach the protein species level. An apoptosis-associated oxidation of cysteine and phosphorylation of a proteasomal protein (Schmidt et al. 2011) shows a direct connection between protein species and function. Many posttranslational modifications, amino acid changes, and alternative splice variants were found in a study of microtubule-associated proteins and their interacting partners from mammalian brain (Kozielski et al. 2011). Signatures for human breast cancer were detected already at the posttranslational modification level in histones (Cuomo et al. 2011). 2-DE/ MS approaches clearly detected protein speciation in murine heart (Schwab et al. 2011), papillary thyroid carcinomas (Zeindl-Eberhart et al. 2011) and in monocytes of chronic kidney disease patients (Scholze et al. 2011).

\section{References}

Cuomo A, Moretti S, Minucci S, Bonaldi T (2011) SILAC-based proteomic analysis to dissect the "histone modification signature" of human breast cancer cells. Amino Acids (in this issue). doi:10.1007/s00726-010-0668-2 
Darula Z, Chalkley RJ, Lynn A, Baker PR, Medzihradszky KF (2011) Improved identification of $O$-linked glycopeptides from ETD data with optimized scoring for different charge states and cleavage specificities. Amino Acids (in this issue). doi:10.1007/ s00726-010-0692-2

Henning S, Mormann M, Peter-Katalinić J, Pohlentz G (2011) Direct analysis of $\alpha$ - and $\beta$-chains of hemoglobins from mammalian blood samples by nanoESI mass spectrometry during in-capillary proteolytic digestion. Amino Acids (in this issue). doi:10.1007/ s00726-010-0671-7

Hoehenwarter W, Chen Y, Recuenco-Munoz L, Wienkoop S, Weckwerth W (2011) Functional analysis of proteins and protein species using shotgun proteomics and linear mathematics. Amino Acids (in this issue). doi:10.1007/s00726-010-0669-1

Jungblut PR, Schlüter H (2011) Towards the analysis of protein species: an overview about strategies and methods. Amino Acids (in this issue). doi:10.1007/s00726-010-0828-4

Klein T, Bischoff R (2011) Physiology and pathophysiology of matrix metalloproteases. Amino Acids (in this issue). doi:10.1007/ s00726-010-0689-x

Kozielski F, Riaz T, DeBonis S, Koehler CJ, Kroening M, Panse I, Strozynski M, Donaldson IM, Thiede B (2011) Proteome analysis of microtubule-associated proteins and their interacting partners from mammalian brain. Amino Acids (in this issue). doi:10.1007/s00726-010-0649-5

Laing S, Unger M, Koch-Nolte F, Haag F (2011) ADP-ribosylation of arginine. Amino Acids (in this issue). doi:10.1007/s00726-0100676-2

Meyer B, Papasotiriou DG, Karas M (2011) 100\% protein sequence coverage: a modern form of surrealism in proteomics. Amino Acids (in this issue). doi:10.1007/s00726-010-0680-6
Schmidt F, Dahlmann B, Hustoft HK, Koehler CJ, Strozynski M, Kloß A, Zimny-Arndt U, Jungblut PR, Thiede B (2011) Quantitative proteome analysis of the $20 \mathrm{~S}$ proteasome of apoptotic Jurkat $\mathrm{T}$ cells. Amino Acids (in this issue). doi:10.1007/s00726-0100575-6

Scholze A, Krueger K, Diedrich M, Räth C, Torges A, Jankowski V, Maier A, Thilo F, Zidek W, Tepel M (2011) Superoxide dismutase type 1 in monocytes of chronic kidney disease patients. Amino Acids (in this issue). doi:10.1007/s00726-010-0763-4

Schwab K, Neumann B, Scheler C, Jungblut PR, Theuring F (2011) Adaptation of proteomic techniques for the identification and characterization of protein species from murine heart. Amino Acids (in this issue). doi:10.1007/s00726-010-0675-3

Seidler J, Zinn N, Haaf E, Boehm ME, Winter D, Schlosser A, Lehmann WD (2011) Metal ion-mobilizing additives for comprehensive detection of femtomole amounts of phosphopeptides by reversed phase LC-MS. Amino Acids (in this issue). doi: 10.1007/s00726-010-0647-7

Sisu E, Flangea C, Serb A, Zamfir AD (2011) Modern developments in mass spectrometry of chondroitin and dermatan sulfate glycosaminoglycans. Amino Acids (in this issue). doi:10.1007/ s00726-010-0682-4

Wiśniewski JR (2011) Tools for phospho- and glycoproteomics of plasma membranes. Amino Acids (in this issue). doi:10.1007/ s00726-010-0796-8

Zeindl-Eberhart E, Liebmann S, Jungblut PR, Mattow J, Schmid M, Kerler R, Rabes HM (2011) Influence of RET/PTC1 and RET/ PTC3 oncoproteins in radiation-induced papillary thyroid carcinomas on amounts of cytoskeletal protein species. Amino Acids (in this issue). doi:10.1007/s00726-010-0733-x 